\title{
PENGARUH SEGMENTASI PASAR TERHADAP KEPUASAN PELANGGAN (NASABAH) PADA BANK BPR JATIM CABANG PONOROGO
}

\author{
Elis Tri Wahyuni \\ Mahasiswi Prodi Pendidikan Ekonomi \\ elis.tri20@yahoo.co.id
}

\begin{abstract}
This study aims to determine the effect of market segmentation of customer satisfaction (Customer) in bank BPR Jatim Branch of Ponorogo. Market Segmentation effect on customer satisfaction as evidenced from $t$ value on the market cementation variable $(X)$ is equal to 17.288 with a significant level of 0.000 . Due 17.288 and $0.000 \leq 1.658 \geq 0.05$ then $H 0$ rejected and Ha accepted. It can be concluded that thitung ttable $\geq$ greater than $t$ table from a significant level of $0.000 t$ less than 0.05 then the research hypothesis $\mathrm{HO}$ and menerimaHa resisting. And it can be seen the value rhitung is 0.748 while rtabel 0,138. This means that the value rhitung $\geq$ rtabel $(0.748 \geq 0.138)$. In this study, $Y=10.264+0,771 X$ constant value of 10.264 means if the variable value market segmentation fixed or constant, the amount of customer satisfaction (customers) amounted to 10.264. This means that in the absence of market segmentation variables pegaruh then customer satisfaction still has a value of 10.264 .
\end{abstract}

Keywords: Market Segmentation, Customer Satisfaction

\begin{abstract}
Abstrak
Penelitian ini bertujuan untuk mengetahui pengaruh segmentasi pasar terhadap kepuasan pelanggan (Nasabah) pada bank BPR Jatim Cabang Ponorogo. Segmentasi Pasar berpengaruh terhadap Kepuasan Pelanggan hal ini dibuktikan dari nilai t hitung pada variabel sementasi pasar $(\mathrm{X})$ adalah sebesar 17,288 dengan tingkat signifikan 0,000. Karena $17,288 \geq 1,658$ dan $0,000 \leq 0,05$ maka $\mathrm{H}_{0}$ ditolak dan $\mathrm{H}_{\mathrm{a}}$ diterima. Dapat disimpulkan $\mathrm{t}_{\text {hitung }} \geq$ $\mathrm{t}_{\text {tabel }}$ yaitu lebih besar dari $\mathrm{t}$ tabel dari tingkat signifikan $\mathrm{t}$ sebesar 0,000 lebih kecil dari 0,05 maka hipotesis penelitian ini menolak $\mathrm{H}_{0}$ dan menerima $\mathrm{H}_{\mathrm{a}}$. Dan dapat diketahui besarnya nilai $r_{\text {hitung }}$ adalah 0,748 sedangkan $r_{\text {tabel }} 0,138$. Ini berarti bahwa nilai $r_{\text {hitung }} \geq r_{\text {tabel }}(0,748 \geq$ $0,138)$. Dalam penelitian ini $Y=10,264+0,771 \mathrm{X}$ nilai konstanta sebesar 10,264 artinya apabila variabel segmentasi pasar bernilai tetap atau konstanta maka besarnya kepuasan pelanggan(nasabah) adalah sebesar 10,264. Artinya tanpa adanya pegaruh variabel segmentasi pasar maka kepuasan pelanggan tetap memiliki nilai 10,264.
\end{abstract}

Kata Kunci: Segmentasi Pasar, Kepuasan Pelanggan

\section{PENDAHULUAN}

Suatu perusahaan dalam melaksanakan kegiatan, baik perusahaan yang bergerak di bidang industri, perdagangan maupun jasa akan berusaha untuk mencapai tujuan yang ingin dicapai sebelumnya. Satu hal yang paling penting yaitu keberhasilan aktivitas di dalam perusahaan dalam mencapai tujuan bukan hanya tergantung pada keunggulan teknologi, dana operasi yang tersedia ataupun 
sarana dan prasarana yang dimiliki tetapi juga tergantung pada aspek segmentasi pasar yang tepat, segmentasi pasar tersebut merupakan hal yang harus diperhatikan oleh sebuah perusahaan. Terutama dalam menghadapi MEA (Masyarakat Ekonomi Asean) yang sudah terjadi pada saat ini. Hal ini memaksa setiap perusahaan harus bekerja dengan lebih efektif dan efisien. Segmentasi pasar yang tepat akan memacu perusahaan untuk dapat lebih produktif dalam memenuhi kebutuhan masyarakat. Segmentasi pasar yang tepat adalah faktor penentu karena dengan adanya segmentasi pasar yang sesuai dengan kebutuhan masyarakat maka sebuah perusahaan akan dapat memuaskan atau memenuhi kebutuhan masyarakat dan tujuan perusahaan akan tercapai secara maksimal.

Melaksanakan segmentasi pasar, kegiatan pemasaran dapat dilakukan secara terarah dan sumber daya perusahaan di bidang pemasaran dapat digunakan secara efektif dan efisien. Kasmir (2006:181), berpendapat "Segmentasi pasar merupakan kegiatan membagi suatu pasar menjadi kelompokkelompok pembeli yang berbeda yang mungkin memerlukan produk atau ramuan pemasaran tersendiri. Bank dalam menjual produknya ke nasabah membagi pasar menjadi beberapa jenis sesuai dengan kriteria yang mereka inginkan".

Segmentasi pasar, sumber daya yang terbatas dapat digunakan secara optimal untuk menghasilkan produk yang dapat memenuhi permintaan pasar, dapat mengalokasikannya kepada potensial yang paling menguntungkan, dan dapat ikut bersaing dalam segmen pasar tertentu, dan dapat menentukan cara-cara promosi yang efektif.

Segmentasi pasar dalam hal ini adalah kegiatan membagi suatu pasar ke dalam kelompok-kelompok yang berbeda. Masingmasing kelompok tersebut terdiri dari konsumen yang mempunyai ciri/sifat yang sama atau hampir sama. Selain itu juga dapat memberikan rasa puas terhadap konsumen guna meningkatkan pendapatan yang sesuai dengan apa yang diinginkan perusahaan.

Agar tujuan perusahaan dapat tercapai secara maksimal, maka harus memperhatikan segmentasi pasar yang baik dan benar agar target yang diinginkan dapat terwujud secara maksimal. Segmentasi pasar yang tepat adalah salah satu aspek yang dapat memberikan rasa puas terhadap konsumen. Agar barang yang ditawarkan kepada konsumen sesuai dengan tingkat kebutuhan sehingga hasil penjualan dapat meningkat sesuai dengan target perusahaan.

Sofjan Assauri (2011:144), berpendapat "Segmentasi pasar adalah suatu cara membedakan pasar menurut golongan pembelian, kebutuhan pemakaian, motif, perilaku dan kebiasaan pembelian, cara penggunaan produk dan tujuan pembelian produk tersebut".

Fandy Tjiptono (2005:64), berpendapat "Segmentasi pasar bisakan diartikan sebagai proses mengelompokkan pasar keseluruhan yang heterogen menjadi kelompok-kelompok atau segmen-segmen yang memiliki kesamaan dalam hal kebutuhan, keinginan, perilaku dan/atau respons terhadap program pemasaran spesifik".

Kotler (2000) dalam Nur Rianto Al Arif, (2012:85) mendefinisikan "Segmentation is process partitioning markets into groups of potential customers with similar needs and characteristics who are likerly to exhibit similar purchase behavior" Artinya : Segmentasi pasar adalah proses pegelompokan ke dalam kelompok pembeli yang potensial yang memiliki kebutuhan yan sama dan atau karakteristik yang disukai serta memperlihatkan hubungan pembelian yang sama.

Swastha (1996) dalam Susatyo Herlambang, (2014:18) mendefinisikan 
"segmentasi pasar adalah kegiatan membagibagi pasar yang bersifat heterogen dari suatu produk ke dalam satuan-satuan (segmen pasar) yang bersifat homogen".

Philip Kotler dan Kevin Lane Keller (2009:138-139) mengemukakan "secara umum, kepuasan (satisfaction) adalah perasaan senang atau kecewa seseorang yang timbul karena membandingkan kinerja yang dipersepsikan produk (atau hasil) terhadap ekspektasi mereka. Jika kinerja gagal memenuhi ekspektasi, pelanggan akan tidak puas. Jika kinerja sesuai dengan ekspektasi, pelanggan akan puas. Jika kinerja melebihi ekspektasi, pelanggan akan sangat puas".

Gunawan Adisaputro (2010:67) mengemukakan "kepuasan adalah perasaan seseorang untuk menjadi senang atau kecewa sebagai hasil dari perbandingan antara kinerja produk yang dipersepsikan (hasil atau outcome) yang dihubungkan dengan harapannya. Bilamana kinerja produk lebih rendah dari harapan sebelumnya dia akan tidak puas dan kecewa. Bilamana kinerja produk sama dengan harapan dia akan puas. Bilamana kinerja melebihi harapannya dia akan menjadi sangat puas.

Yamit (2005:78) mengemukakan "kepuasan pelanggan merupakan evaluasi purna beli atau hasil evaluasi setelah membandingkan apa yang dirasakan dengan harapannya. Dari penjelasan tersebut dapat disimpulkan bahwa kepuasan pelanggan adalah hasil (outcome) yang dirasakan atas penggunaan produk dan jasa, sama atau melebihi harapan yang diinginkan".

Yazid, (2003:67) berpendapat "segmentasi pasar yang berhasil akan mampu memuaskan konsumen yang ada sekarang ataupun konsumen potensial dari pasar yang terdefinisi secara jelas". Ini berarti perusahaan perlu memahami sikap konsumen, preferensi konsumen, serta keuntungan yang diharapkan akan diperoleh konsumen maupun organisasi. Jadi, defenisi pasar sasaran dan persyaratannya adalah langkah penting dalam segmentasi.

Segmentasi pasar yang tepat perusahaan diharapkan dapat meningkatkan hasil penjualan barang, sebelum menetapakan segmentasi pasar hendaknya diadakan perencanaan yang baik dengan memperhatikan segala faktor, agar segmentasi pasar yang akan dilaksankan dapat berjalan sesuai dengan yang diharapkan. Tentu saja hal ini harus sesuai dengan maksud dapat meningkatkan jumlah penjualan yang diharapkan serta rasa puas untuk para konsumen.

Penelitian tentang segmentasi pasar ini diharapkan bisa membantu untuk mewujudkan suatu tujuan perusahaan. Berdasarkan hal tersebut penulis tertarik mengambil topik dalam penelitian ini adalah Pengaruh Segmentasi Pasar Terhadap Kepuasan Pelanggan (Nasabah) Pada bank BPR Jatim Cabang Ponorogo. 


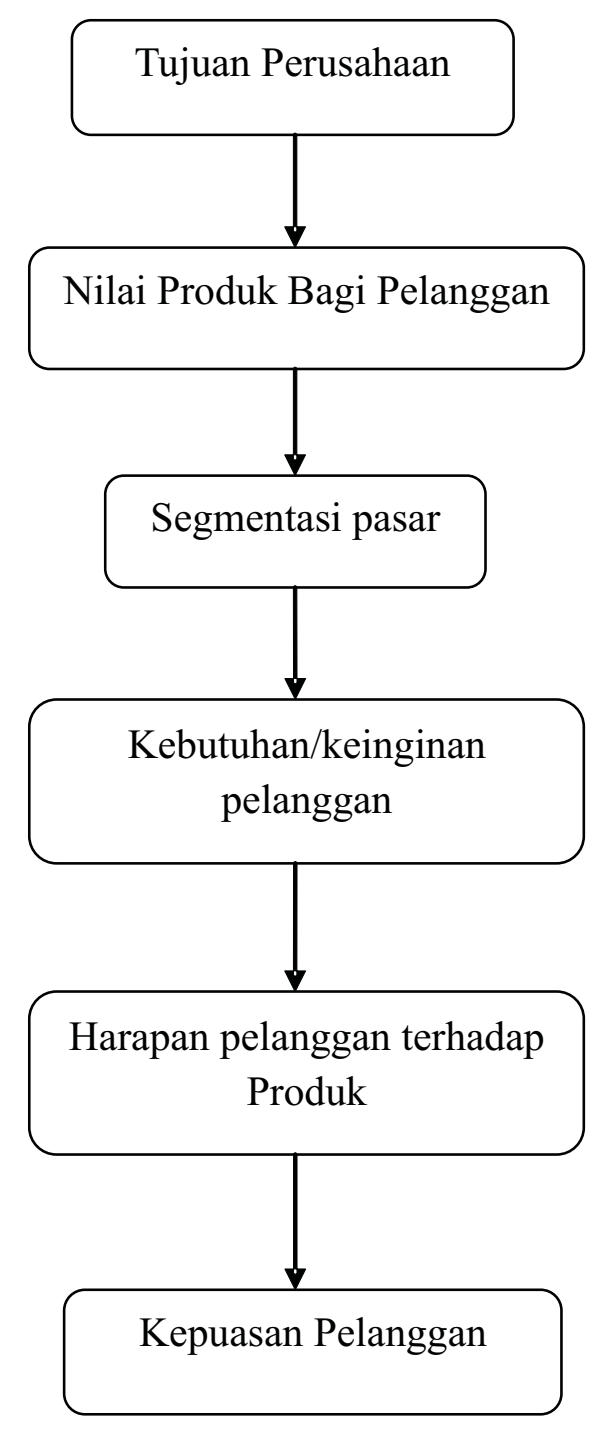

\section{Gambar 2.1 Kerangka berfikir}

Dari gambar di atas dapat disimpulkan bahwa sebuah perusahaan harus memiliki tujuan agar hasil yang diharapkan sesuai dengan target perusahaan. Atau dalam arti memiliki segmentasi pasar yang jelas. Dengan memiliki produk yang sesuai dengan kebutuhan pelanggan dan harapan pelanggan maka dapat tercipta tingkat kepuasan pelanggan (Nasabah) Bank BPR Jatim Khususnya Nasabah produk kredit modal kerja.

\section{METODE PENELITIAN}

Penelitian dilakukan pada perusahaan "bank BPR Jatim Cabang Ponorogo" di J1.MH Thamrin No.51 Ponorogo Jawa Timur
Alasan pemilihan tempat tersebut dikarenakan "bank BPR Jatim Cabang Ponorogo" merupakan perusahaan yang bergerak dalam bidang pelayanan dan jasa keuangan dan merupakan salah satu perusahaan yang menyediakan pelayanan dan jasa keuangan di wilayah Ponorogo yang sangat diminati oleh para Pelanggan.

Desain penelitian dalam penelitian ini adalah penelitian konklusif. Menurut Juliansyah Noor (2013:110), penelitian konklusif merupakan penelitian yang bertujuan untuk menguji hipotesis. Penelitian konklusif didesain untuk membantu pengambilan keputusan dalam menentukan, mengewaluasi dan memilih alternatif terlebih dalam memecahkan suatu masalah.

Metode merupakan dasar pokok dalam suatu penelitian, sehingga dalam metode tersebut diharapkan dapat memperoleh data yang akurat dan dapat dipertanggungjawbkan. "Metode dalam penelitian ini peneliti menggunakan metode deskriptif. Penelitian deskriptif ini bertujuan untuk mendiskripsikan sifat atau karakteristik dari suatu gejala, peristiwa, kejadian yang terjadi saat ini Juliansyah Noor (2011:111)".

Penelitian deskriptif memusatkan perhatian kepada masalah aktual dan peneliti berusaha mendiskripsikan peristiwa dan kejadian yang menjadi pusat perhatian tanpa memberikan perlakuan khusus terhadap peristiwa tersebut (Noor, 2011:111).

Dalam menyelesaikan penelitian ini peneliti menggunakan jenis penelitian kuantitatif. "Penelitian kuantitatif adalah metode penelitian yang berlandaskan pada filsavat positivisme, digunakan untuk meneliti pada populasi atau sampel tertentu, pengumpulan data menggunakan instrument penelitian, analisis data bersifat kuantitatif/statistik, dengan tujuan untuk menguji hipotesis yang telah ditetapkan" (Sugiyono, 2010:14).

Metode deskriptif digunakan dalam 
penelitian ini karena supaya memperoleh data yang akurat pada saat penelitian dengan menggunkan angket sebagai tehnik mengumpulan data dan sample sebagai sasaran pengumpulan data yang bersifat kuantitatif.

Penelitian ini dilakukan untuk mengetahui apakah segmentasi pasar (X) berpengaruh terhadap kepuasan pelanggan (Nasabah) (Y) pada Bank BPR Jatim Cabang Ponorogo.

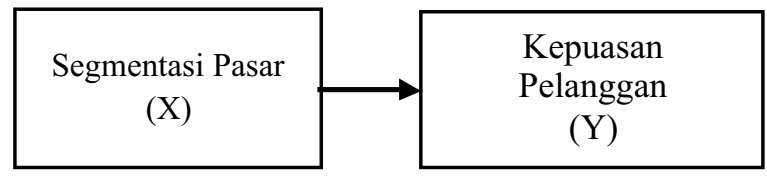

Gambar Desain Penelitian

Populasi dalam penelitian ini adalah pelanggan (Nasabah) Bank BPR Jatim Cabang Ponorogo.

Teknik sampling yang digunakan untuk pengambilan sampel adalah teknik sampling insidental. Sampling insidental adalah "teknik penentuan sampel berdasarkan kebetulan, yaitu siapa saja yang secara kebetulan/insidental bertemu dengan peneliti dapat digunakan sebagai sampel bila dipandang orang yang kebetulan ditemuai cocok sebagai sumber data" (Sugiyono, 2015:85).

Adapun sampel dalam penelitian ini adalah nasabah yang menggunkan kredit modal kerja. Untuk menghitung digunakan rumus perhitungan sebagai berikut:

Rumus Slovin: $\mathrm{n}=\frac{\mathrm{N}}{1+\overline{\mathrm{Ne}}^{2}}$

Keterangan :

$\mathrm{n}=$ Sampel

$\mathrm{N}=$ Jumlah Populasi

$\mathrm{e}=$ Perkiraan Jumlah Kesalahan

(Syofian Siregar, 2014:61)

Diketahui :

$\mathrm{N}=578$

$\mathrm{e}=0,05(5 \%)$
Jawab :

$\mathrm{n}=\frac{\mathrm{N}}{1+\mathrm{Ne}^{2}}=\frac{578}{1+578(0.05)^{2}}=236,400$

(dibulatkan 237)

\section{Teknik Pengumpulan Data}

Teknik pengumpulan data dalam penelitian adalah:

1. Observasi

Menurut Hadi (dalam Sugiyono, 2015:145) mengemukakan bahwa "observasi merupakan suatu proses yang kompleks, suatu proses yang tersusun dari berbagai proses biologis dan psikologis. Dua di antara yang terpenting adalah proses - proses pengamatan dan ingatan".

Dalam penelitian ini pengumpulan data dilakukan dengan cara peninjauan secara langsung pada bank BPR Jatim Cabang Ponorogo untuk memperoleh data yang diperlukan untuk kelancaran penyusunan penelitian yang berkaitan.

Kuesioner yang disebar untuk memperoleh data tentang tanggapan responden tentang segmentasi pasar dan kepuasan pelanggan. Kuesioner berisikan 20 daftar pertanyaan yang terdiri dari 10 pertanyaan segmentasi pasar dan 10 pertanyaan kepuasan pelanggan.

2. Kuesioner/Angket

Menurut Sugiyono (2015:142) "kuesioner merupakan teknik pengumpulan data yang dilakukan dengan cara memberi seperangkat pertanyaan atau pernyataan tertulis kepada responden untuk dijawabnya". Dalam penelitian ini, kuesioner berupa pertanyaan-pertanyaan yang akan diberikan kepada para pelanggan bank BPR Jatim Cabang Ponorogo untuk mengetahui tentang macam - macam barang yang ditawarkan yang sesuai dengan kebutuhan pelanggan.

Menurut Hamid Darmadi (2011:106) skala likert digunakan untuk mengukur persepsi atau sikap seseorang. 
Skala ini menilai sikap atau tingkah laku yang diinginkan oleh para peneliti dengan cara mengajukan beberapa pertanyaan kepada responden. Kemudian responden diminta memberikan pilihan jawaban atau respon dalam skala ukur yang telah disediakan.

Dalam penelitian ini digunakan angket untuk mengetahui respon nasabah tentang segmentasi pasar dan kepuasan pelanggan.

3. Dokumentasi

Menurut Suharsimi Arikunto (2010:274), "Dokumentasi adalah mencari data, mengenai hal - hal atau variabel yang berupa catatan, transkrip, buku, surat kabar, majalah, prasasti, notulen rapat, legger, agenda, dan sebagainya”.

Dalam penelitian ini, dokumentasi berupa pengumpulan data seperti data berbagai gambar jenis produk yang ditawarkan serta manfaat bagi para pelanggan (nasabah).

\section{Instrumen Penelitian}

Menurut Suharsimi Arikunto (2010:203), instrumen penelitian adalah "alat atau fasilitas yang digunakan oleh peneliti dalam mengumpulkan data agar pekerjaannya lebih mudah dan hasilnya lebih baik, dalam arti lebih cermat, lengkap, dan sisitematis sehingga lebih mudah diolah".

Instrumen yang digunakan dalam penelitian ini adalah kuesioner yang merupakan teknik pengumpulan data melalui daftar pertanyaan yang diajukan kepada responden. Dalam penelitian ini menggunakan skala likert untuk mengukur instrumen yang digunakan.

\section{Teknik Analisis Data}

Dalam suatu penelitian, untuk menguji suatu data digunakan teknik untuk menganalisisnya. Analisis yang dimaksudkan dalam penelitian ini adalah :

\section{a. Uji Validitas}

Validitas adalah "suatu ukuran yang menunjukkan tingkat-tingkat kevalidan atau kesahihan sesuatu instrumen”. (Arikunto, 2010:211). Rumus dan kriteria yang dapat digunakan untuk uji validitas kuesioner adalah sebagai berikut: Validitas angket diuji dengan teknik logis, yakni validitas instrument yang diukur dari kecocokannya sehingga secara logika dapat diterima.

b. Uji Reliabilitas

Menurut Suharsimi Arikunto (2010:221) reliabilitas menunjukkan pada satu pengertian bahwa sesuatu instrumen cukup dapat dipercaya untuk digunakan sebagai alat pengumpul data karena intrumen tersebut sudah baik.

Reliabilitas menunjuk pada satu pengertian bahwa sesuatu instrument cukup dapat dipercaya untuk digunakan sebagai alat pengumpul data karena instrument tersebut sudah baik (Suharsimi Arikunto, 2010:221). Uji reabilitas dalam penelitian ini dilakukan dengan menggunakan rumus Alpha dan alat bantu program SPSS Versi 22.0. Penggunaan rumus ini didasarkan pada alasan karena skor yang diperoleh bukan 1 dan 0 , tetapi 1 sampai dengan 4.

Dalam Siregar (2012:175), "kriteria suatu instrumen penelitian dikatakan reliabel dengan menggunakan teknik Alpa Cronbach bila koefisien reliabilitas $\left(\mathrm{r}_{11}\right)>0,6$ ".

1. Uji Asumsi Klasik

Uji asumsi digunakan untuk mengetahui pola dan varian serta kelinieritasan dari suatu populasi (data). Apakah populasi atau data berdistribusi normal atau tidak, atau juga uji dapat dgunakan untuk mengetahui apakah populasi mempunyai beberapa varian yang sama, serta untuk menguji kelinieritasan data.

a. Uji Normalitas

Uji Normalitas "bertujuan untuk 
menguji apakah dalam model regresi variabel pengganggu atau residual memiliki distribusi normal (Imam Gozali, 2011 :160)". Menurut Duwi Priyatno (2013:56) "syarat dalam analisis parametrik yaitu distribusi data harus normal. Pengujian menggunakan uji KolmogorovSmirnov (Analisis Explore) untuk mengetahui apakah distribusi data pada tiap-tiap variabel normal atau tidak". Kriteria pengambilan keputusan yaitu jika signifikansi $>0,05$ maka data distribusi normal dan jika signifikansi $<0,05$ maka data tidak berdistribusi normal. Kriteria pengambilan keputusan dalam pengujian Normal Probability yaitu sebagai berikut :

1. Jika data menyebar di sekitar garis diagonal dan mengikutiarah diagonal, maka model regresi memenuhi asumsi normalitas.

2. Jika data menyebar jauh dari garis diagonal, maka regresi tidak memenuhi asumsi normalitas.

Dalam penelitian pengaruh Segmentasi Pasar terhadap Kepuasan Pelanggan (Nasabah), analisis yang digunakan adalah dengan menggunakan regresi linier sederhana. Syofian Siregar (2014: 379).

Metode pengujian terhadap hipotesis yang diajukan dilakukan pengujian secara parsial dan pengujian secara simultan serta analisis koefisien determinasi $\left(\mathrm{R}^{2}\right)$ (Ghozali, 2005). Pengujian hipotesis tersebut sebagai berikut:

a. Uji Koefisien determinasi

Koefisien determinasi $\left(\mathrm{R}^{2}\right)$ "digunakan untuk mengetahui sampai seberapa besar presentasi variasi variabel bebas pada model dapat diterangkan oleh variabel terikat (Gujarati,1995)". Koefisien determinasi $\left(\mathrm{R}^{2}\right)$ dinyatakan dalam persentase yang nilainya berkisar antara
$0<\mathrm{R}^{2}<1$. Nilai $\mathrm{R}^{2}$ yang kecil berarti kemampuan variabel-variabel independen dalam menjelaskan variasi variabel independen amat terbatas. Nilai yang mendekati satu berarti variabel-variabel independen memberikan hampir semua informasi yang dibutuhkan untuk memprediksi variasi variabel independen. Secara umum koefisien determinasi untuk data silang (crosssection) relatif rendah karena adanya variasi yang besar antara masing-masing pengamatan, sedangkan untuk data runtun waktu (time series) biasanya mempunyai nilai koefisien determinasi tinggi.

b. Uji Statistik $\mathrm{t}$

Menurut Syofian Siregar (2014:195)

Uji $\mathrm{t}$ digunakan untuk mengetahui pernyataan atau dugaan yang dihipotesiskan oleh si peneliti. Uji-t untuk satu variabel dibagi menjadi dua kategori, yaitu :

1) Uji-t satu variabel dengan satu arah kri dan kanan (one tail)

2) Uji-t untuk satu variabel dengan dua arah (two tail)

\section{HASIL DAN PEMBAHASAN Variabel Segmentasi Pasar dan Kepuasan Pelanggan (Nasabah)}

Dideskripsikan bahwa variabel Segmentasi Pasar dengan jumlah data sebanyak 237 orang memiliki deskripsi data sebagai berikut : a) Nilai rata-rata hitung (mean) 35,39, b) Median 35,00, c) Modus 35 d) Nilai Minimum 27, f) Nilai Maximum 45.

Dari hasil penelitian, yang diolah kuisioner 237 responden, yang berada diatas nilai rata-rata sebanyak 137 segmentasi pasar atau $57,8 \%$ sedangkan yang dibawah ratarata sebanyak 100 segmentasi pasar atau 42,2\%. Artinya nasabah BPR Jatim Cabang Ponorogo setuju dengan adanya segmentasi pasar. 
Dideskripsikan bahwa variabel Kepuasan pelanggan dengan jumlah data sebanyak 237 orang memiliki deskripsi data sebagai berikut: a) Nilai rata-rata hitung (mean) 37,55, Median 38,00, c) Modus 39, d) Standar Deviasi 3,194, e) Nilai Minimum 32 f) Nilai Maksimum 46.

Dari hasil penelitian, kepuasan pelanggan (nasabah) di atas rata-rata hitung sebanyak 121 orang atau 51,1\% dan yang dibawah rata-rata hitung sebanyak 116 orang atau 48,9\%. Hal ini berarti kepuasan pelanggan (nasabah) pada BPR Jatim Cabang Ponorogo Baik.

\section{Hasil Uji Regresi}

Berdasarkan persamaan regresi di atas dapat dijelaskan sebagai berikut:

1. Konstanta sebesar 10,264 artinya apabila variabel segmentasi pasar bernilai tetap atau konstanta maka besarnya kepuasan pelanggan(nasabah) adalah sebesar 10,264. Artinya tanpa adanya pegaruh variabel segmentasi pasar maka kepuasan pelanggan tetap memiliki nilai 10,264.

2. Koefesien regresi segmentasi pasar (X) sebesar 0,771 berarti bahwa apabila terjadi peningkatan variabel sebesar satu maka besarnya kepuasan pelanggan (nasabah) (Y) akan naik sebesar 0,771 satuan. Koefesien bernilai positif artinya segmentasi pasar berpengaruh positif terhadap kepuasan pelanggan.

\section{Hasil Uji Koefisien Determinasi}

Berdasarkan analisis, dapat diketahui besarnya nilai $r_{\text {hitung }}$ adalah 0,748 sedangkan $r_{\text {tabel }} 0,138$. Ini berarti bahwa nilai $r_{\text {hitung }} \geq r_{\text {tabel }}$ $(0,748 \geq 0,138)$, atau dapat disimpulkan tolak $\mathrm{H}_{0}$, artinya ada pengaruh yang signifikan antara Segmentasi Pasar dan Kepuasan pelanggan (Nasabah) pada bank BPR Jatim Cabang Ponorogo.

Dalam uji determinasi yang diperoleh nilai $\mathrm{R}^{2}$ ( $\mathrm{R}$ Square) yang digunakan untuk mengetahui seberapa besar prosentase sumbangan Segmentasi Pasar terhadap Kepuasan pelanggan. Berdasarkan hasil analisis diatas dapat diketahui nilai $\mathrm{R}^{2}$ adalah 0,560. Jadi sumbangan pengaruh dari Segmentasi Pasar terhadap Kepuasan pelanggan yaitu $56 \%$ sedangkan sisanya sebesar 44\% dipengaruhi oleh faktor lain.

Hipotesis yang dikemukakan sebagai berikut:

1. Tolak $\mathrm{H}_{0}$, apabila $\mathrm{r}_{\text {hit }} \geq \mathrm{r}_{\text {tab }}$ berarti ada hubungan yang signifikan antara Segmentasi Pasar terhadap Kepuasan pelanggan (Nasabah) pada bank BPR Jatim Cabang Ponorogo

2. Terima $\mathrm{H}_{0}$, apabila $\mathrm{r}_{\text {hit }} \leq \mathrm{r}_{\text {tabel }}$ berarti tidak ada hubungan yang signifikan antara Segmentasi Pasar terhadap Kepuasan pelanggan (Nasabah) pada bank BPR Jatim Cabang Ponorogo

\section{Hasil Uji T}

Nilai t hitung pada variabel sementasi pasar (X) adalah sebesar 17,288 dengan tingkat signifikan 0,000. Karena 17,288 $\geq$ 1,658 dan $0,000 \leq 0,05$ maka $\mathrm{H}_{0}$ ditolak dan $\mathrm{H}_{\mathrm{a}}$ diterima. Dapat disimpulkan $t_{\text {hitung }} \geq t_{\text {tabel }}$ yaitu lebih besar dari t tabel dari tingkat signifikan $t$ sebesar 0,000 lebih kecil dari 0,05 maka hipotesis penelitian ini menolak $\mathrm{H}_{0}$ dan menerima $\mathrm{H}_{\mathrm{a}}$. Hal ini menunjukkan bahwa variabel segmentasi pasar secara parsial memiliki pengaruh yang signifikan terhadap kepuasan pelanggan pada bank BPR Jatim Cabang Ponorogo.

\section{Simpulan Hasil Analisis}

Penelitian ini menunjukkan kondisi penilaian responden terhadap variabelvariabel penelitian ini sudah baik hal ini dapat ditunjukkan dari tanggapan para responden terhadap masing-masing variabel yang bersangkutan. Dari hasil penelitian ini makan 
dapat disimpulkan bahwa variabel independen yaitu segmentasi pasar memiliki pengaruh yang signifikan terhadap kepuasan pelanggan (nasabah) pada BPR Jatim Cabang Ponorogo. Penjelasan dari variabel dapat dijelaskan sebagai berikut:

Berdasarkan analisis secara parsial, hasil penelitian membuktikan bahwa variabel independen (segmentasi pasar) mempunyai pengaruh yang signifikan terhadap kepuasan pelanggan pada BPR Jatim Cabang Ponorogo. Variabel independen tersebut dianggap penting karena apabila Segmentasi Pasar tepat sasaran maka produk yang ditawarkan dapat sesuai dengan yang dibutuhkan masyarakat sehingga rasa puas itu akan timbul dibenak para pelanggan (nasabah) Bank BPR jatim Cabang Ponorogo.

Segmentasi pasar merupakan faktor yang paling penting agar masyarakat yang menggunakan jasa bank dapat terpuaskan dengan produk yang ditawakan. Segmentasi pasar yang baik akan mampu memberikan produk yang sesuai dengan kebutuhan masyarakat dan nasabah yang memakai jasa bank dapat tercipta rasa puas sehingga apa yang diharapkan perusahaan dapat sesuai dengan rencana dan dapat meningkatkan jumlah nasabah pada Bank BPR Jatim Cabang Ponorogo.

\section{Pembahasan}

Pengujian hipotesis dengan menggunakan uji statistik t menunjukkan $\mathrm{H}_{a}$ diterima. Uji $\mathrm{t}$ menunjukkan bahwa $\mathrm{H}_{\mathrm{o}}$ ditolak. Berdasarkan hasil penelitian menunjukkan bahwa Segmentasi Pasar mempunyai hubungan sekaligus pengaruh yang signifikan terhadap Kepuasan pelanggan pada Bank BPR Jatim Cabang Ponorogo. Dapat disimpulkan bahwa dengan segmentasi pasar yang baik maka semua nasabah akan terpuaskan dengan semua produk yang ada karena sesuai dengan kebutuhan mereka.
Pengaruh Segmentasi Pasar terhadap Kepuasan Pelanggan (Nasabah). Hasil penelitian menunjukkan bahwa tingkat signifikan $\mathrm{t}$ sebesar 0,000 lebih kecil 0,05 $(0,000 \leq 0,05)$ maka hipotesis penelitian ini menolak $\mathrm{H}_{\mathrm{o}}$ dan menerima $\mathrm{H}_{\mathrm{a}}$. Hipotesis yang menyatakan menerima Ha menunjukkan bahwa variabel segmentasi pasar diterima. Oleh karena itu sebuah perusahaan harus mempertimbangkan segmentasi pasar yang tepat sehingga produk yang ditawarkan sesuai dengan kebutuhan atau yang diharapkan masyarakat sehingga rasa puas itu akan timbul dan akan menggunakan jasa ulang.

Nilai uji t yang menjelaskan besarnya pengaruh masing-masing variabel bebas terhadap variabel terikat secara sendirisendiri (parsial) pada analisis di atas menjelaskan bahwa variabel segmentasi pasar memberikan pengaruh. Nilai uji $t$ variabel segmentasi pasar terhadap kepuasan pelanggan (nasabah) sebesar 17, 288 lebih besar dari $t_{\text {tabel }}$ sehingga variabel segmentasi pasar berpengaruh terhadap kepuasan pelanggan (nasabah).

Berdasarkan hasil penelitian menunjukkan bahwa segmentasi pasar mempunyai pengaruh terhadap kepuasan pelanggan. Dengan adanya Segmentasi Pasar yang baik akan dapat mendorong Kepuasan pelanggan hal ini sejalan dengan pendapat yang dikemukakan Yazid, (2003:67) "Segmentasi pasar adalah proses pengelompokan konsumen yang semula heterogen ke dalam segmen-segmen yang mempunyai keinginan, kebutuhan, preferensi dan perilaku pembelian yang sama atau homogen. Segmentasi pasar yang berhasil akan mampu memuaskan konsumen yang ada sekarang ataupun konsumen potensial dari pasar yang terdefinisi secara jelas. Dengan demikian maka pelanggan dapat terpuaskan sesuai dengan produk-produk yang mereka inginkan atau sesuai dengan kebutuhan.

Suatu penelitian dikatakan relevan 
apabila didukung oleh hasil penelitian orang lain. Hasil penelitian yang dapat dijadikan pendukung adalah hasil penelitian dengan variabel penelitian yang hampir sama tetapi masih dalam pembahasan yang sama.

Penelitian yang digunakan penulis sebagai pendukung hasil penelitian ini adalah penelitian yang ditulis oleh Nazir tahun 2013 yang berjudul "Pengaruh Segmentasi Pasar Terhadap Kepuasan Konsumen Sharp Electronic Indonesia di Wilayah Citayam" hasil penelitian yang ditulis tersebut menunjukkan bahwa segmentasi pasar dan kepuasan konsumen mempunyai pengaruh yang kuat dan positif, ini berarti bila segmentasi pasar lebih baik maka berpengaruh sangat positif pula pada kepuasan konsumen perusahaan tersebut dan dalam penelitian yang berjudul "Analisis Penentuan Segmen, Target, dan Posisi Pasar Home Care Di rumah Sakit Al-Islam Bandung" oleh Dadang Munandar (2005) hasil simpulan dalam penelitian ini apabila segmentasi pasar jelas dan tepat pada sasaran maka tahap perkenalan suatu produk ke masyarakat dapat tersalurkan dengan baik, Pada masa pertumbuhan produk semakin dapat diterima dan pasar mulai menginginkan variasi produk, maka dapat diterapkan pemasaran serba aneka. Sehingga masyarakat lebih puas dengan produk yang kita tawarkan.

Penelitian ini dilakukan di bank BPR Jatim Cabang Ponorogo menunjukkan bahwa segmentasi pasar berpengaruh terhadap kepuasan pelanggan (nasabah).

\section{PENUTUP}

\section{Simpulan}

Berdasarkan hasil analisis data dari penelitian yang telah dilakukan terhadap pelanggan (nasabah) BPR Jatim Cabang Ponorogo maka dapat disimpulkan sebagai berikut:

1. Segmentasi pasar merupakan faktor yang dominan dalam penentuan kepuasan pelanggan. Segmentasi pasar yang tepat akan mampu meberikan rasa puas terhadap pelanggan (nasabah) sehingga akan mengakibatkan pembelian jasa ulang. Dari hasil penelitian dengan judul "Pengaruh Segmentasi Pasar Terhadap Kepuasan Pelanggan (Nasabah) Pada BPR Jatim Cabang Ponorogo", yang diolah kuisioner 237 responden, yang berada diatas nilai rata-rata sebanyak 137 segmentasi pasar atau $57,8 \%$ sedangkan yang dibawah rata-rata sebanyak 100 segmentasi pasar atau 42,2\%. Artinya nasabah BPR Jatim Cabang Ponorogo setuju dengan adanya segmentasi pasar. Semakin tepat segmentasi pasar maka produk yang ditawarkan akan semakin tepat sasaran dan sesuai dengan tingkat kebutuhan masyarakat sehingga masyarakat yang menggunakan produk tersebut akan timbul rasa puas.

2. Kepuasan pelanggan (nasabah) merupakan tanggapan emosional setelah masyarakat menggunakan jasa/produk. Dari hasil penelitan yang diolah dari kuisioner sebanyak 237 responden yang berada diatas rata-rata hitung sebanyak 121 orang atau $51,1 \%$ dan yang di bawah rata-rata hitung sebanyak 116 orang atau $48,9 \%$. Hal ini berarti kepuasan pelanggan (nasabah) pada BPR Jatim Cabang Ponorogo Baik.

3. Segmentasi pasar mempunyai pengaruh yang signifikan terhadap kepuasan pelanggan (nasabah) BPR Jatim Cabang Ponorogo. Terbukti dari hasil analisis regresi yaitu $Y=10,264+0,771 \mathrm{X}$. Artinya ada pengaruh antara segmentasi pasar terhadap kepuasan pelanggan (nasabah) BPR Jatim Cabang Ponorogo. Nilai $t$ hitung pada variabel segmentasi pasar (X) adalah sebesar 17,288 $\geq 1,658$ dan $0,000 \leq$ 0,05 maka $\mathrm{H}_{0}$ ditolak dan $\mathrm{H}_{\mathrm{a}}$ diterima. 
Dapat disimpulkan $t_{\text {hitung }} \geq t_{\text {tabel }}$ yaitu lebih besar dari $t$ tabel dari tingkat signifikan $t$ sebesar 0,000 lebih kecil dari 0,05 maka hipotesis penelitian ini menolak $\mathrm{H}_{0}$ dan menerimaH $\mathrm{H}_{\mathrm{a}}$.

\section{Saran}

Berdasarkan kesimpulan yang diperoleh di dalam penelitian, maka peneliti mengajukan saran kepada bank BPR Jatim Cabang Ponorogo, Karyawan, dan Peneliti sebagai berikut :

\section{Bagi BPR Jatim Cabang Ponorogo}

a. Perlu adanya peningkatan segmentasi pasar yang lebih spesifik sehingga pasar sasaran dapat lebih maksimal.

b. Perlu meningkatkan pelayanan door to door sehingga proses pencairan kredit modal kerja lebih mudah.

c. Perlu menambah jenis produk yang lebih tepat dan sesuai dengan kebutuhan masyarakat sesuai dengan kemampuannya.

\section{Bagi Karyawan}

a. Perlu adanya peningkatan komunikasi sehingga pelanggan tidak jenuh ketika menunggu antrian.

b. Karyawan mampu mempertahankan bahkan cara komunikasi yang baik akan mampu meninggkatkan omset perusahaan, sehingga apa yang diharapkan perusahaan dapat tercapai secara maksimal.

\section{Bagi Peneliti}

Bagi peneliti selanjutnya, sebaiknya mengembangkan penelitian dengan menggunakan variabel bebas lain selain segmentasi pasar, karena selain segmentasi pasar masih banyak faktor lain yang mempengaruhi kepuasan pelanggan (nasabah). Contoh: Seperti mutu, loyalitas pelanggan, serta kwalitas produk.

\section{DAFTAR PUSTAKA}

Adisaputro Gunawan. 2010. Manajemen Pemasaran. Yogyakarta. Unit Penerbit Percetakan Sekolah Tinggi Ilmu Manajemen YKPN.

Al Arif Nur Rianto. 2012. Dasar - Dasar Pemasaran Bank Syariah. Bandung. Alfabeta

Arikunto Suharsimi. 2010. Prosedur Penelitian. Jakarta. Rineka Cipta.

Assauri Sofjan. 2011. Manajemen Pemasaran. Jakarta. PT Raja Grafindo Persada.

Darmadi Hamid. 2011. Metode Penelitian Pendidikan. Bandung. Alfabeta

Ghozali M.Com Prof. Dr.H Imam. 2011. Aplikasi Analisis Multivariate dengan Program IBM SPSS 19. Semarang. Badan Penerbit Universitas Diponegoro.

Herlambang Susatyo. 2014. Basic Marketing Dasar - Dasar Pemasaran. Yogyakarta. Gosyen Publishing.

Kasmir. 2006. Manajemen Perbankan. Jakarta. PT Raja Grafindo Persada.

Kotler Philip dan Keller Kevin Lane. 2009. Manajemen Pemasaran. PT Gelora Aksara Pratama.

Nasution M.N. 2004. Manajemen Jasa Terpadu. Bogor Selatan. Ghalia Indonesia.

Noor Juliansah. 2011. Metodologi Penelitian. Jakarta. Kencana Prenada Media Group. 
Priyatno Duwi. 2013. Analisis Korelasi, Regresi, dan Multivariate dengan SPSS. Yogyakarta. Penerbit Gava Media.

Siregar M.M Ir Syofian. 2012. Statistika Deskriptif untuk Penelitian. Jakarta. PT Raja Grafindo Persada.

Siregar M.M Ir Syofian. 2014. Statistik Parametrik Untuk Penelitian Kuantitatif. Jakarta. PT Bumi Aksara.

Sugiyono. 2011. Metode Penelitian Pendidikan. Bandung. Alfabeta

Sugiyono. 2015. Metode Penelitian Kuantitatif Kualitatif dan $R \& D$. Bandung. Alfabeta.

Sunyoto Danang. 2013. Dasar - Dasar Manajemen Pemasaran. Yogyakarta. CAPS.

Tjiptono Fandy. 2005. Pemasaran Jasa. Malang. Bayumedia Publishing

, Fandy. 2008. Strategi Pemasaran. Yogyakarta. CV Andi Offset.

Umar Husain. 2005. Studi Kelayakan Bisnis. Jakarta. PT Gramedia Pustaka Utama

Utami Christina Whidya. 2006. Manajemen Ritel. Jakarta. Salemba Empat

Yamit Zulian. 2005. Manajemen Kualitas Produk Dan Jasa. Yogyakarta. Ekonisia
Yazid. 2003. Pemasaran Jasa. Yogyakarta. EKONISIA Kampus Fakultas Ekonomi UII

http://jesl.journal.ipb.ac.id/index.php/jurnal mpi/article/view/763/4114 (Diunduh pada tanggal 16 april 2016) Jam 22.49 WIB

http://eprints.undip.ac.id/17411/1/FIRA_PU SPITA.pdf (Diunduh pada tanggal 20 April 2016) Jam 23.24 WIB

http://jurnal.unikom.ac.id/_s/data/jurnal/v06 -n02/vol-6-artikel-12.pdf/pdf/vol-6artikel-12.pdf (Diunduh pada tanggal 28 Juli 2016) Jam 22.12 WIB

https://www.google.co.id/?gws_rd=cr,ssl\&ei $=4 \mathrm{~A} \mathrm{~K}$ e V $8-5 \mathrm{D}$ o $\mathrm{P}$ vgSV9bGYAQ\#q=JURNAL+NOMI $\mathrm{NAL}+\% 2 \mathrm{~F}+\mathrm{VOLUME}+\mathrm{IV}+\mathrm{NOMO}$ $\mathrm{R}+1+\% 2 \mathrm{~F}+\mathrm{TAHUN}+2015$ (Diunduh pada tanggal 31 Juli 2016) Jam 20.54 WIB

https://www.google.co.id/url?sa=t\&rct=j\&q $=\&$ esrc $=$ S\& source $=$ web \&cd $=3 \& \mathrm{cad}$ $=$ rja $\&$ uact $=8 \&$ ved $=0$ ahUKEwjA9Y WZmqPOAhWFW5QKHaLZDakQ FggrMAI\&url=http $\% 3 \mathrm{~A} \% 2 \mathrm{~F} \% 2 \mathrm{Fejo}$ urnal.stiepena.ac.id $\% 2$ Findex.php $\% 2$ Ffokus \%2Farticle\%2Fdownload\%2F 33\%2F33\&usg=AFQjCNFc9COMF b5aRhRQBSq7I_xnU6QMug\&sig2= RkdF5FNGHaNiDYciw9W6rA\&bv $\underline{m}=$ bv.128617741,d.dGo (Diunduh pada tanggal 02 Agustus 2016) Jam $22.00 \mathrm{WIB}$ 